\title{
Possible climate preconditioning on submarine landslides along a convergent margin, Nankai Trough (NE Pacific)
}

\author{
Katrina Kremer ${ }^{1,2^{*}}$, Muhammed O. Usman ${ }^{1}$, Yasufumi Satoguchi ${ }^{3}$, Yoshitaka Nagahashi ${ }^{4}$, \\ Sunil Vadakkepuliyambatta ${ }^{5}$, Giuliana Panieri ${ }^{5}$ and Michael Strasser ${ }^{1,6}$
}

\begin{abstract}
Submarine landslides are major agents of sediment mass transfer from the shallow to deep sea. Due to their rapid emplacement and tsunamigenic potential, such landslides are significant geohazards for society and offand on-shore infrastructure. The relationship between climate change and the occurrence of submarine landslides is widely debated. However, there is a lack of continuous long-term submarine landslide records with which to comprehensively understand the relationship between climate-driven forces and submarine landslide occurrence. Here, using oxygen isotope stratigraphy in combination with tephrochronology, we date a 1 Myr continuous record of six landslide deposits (at 13.0-14.2, 323-339, 372-384, 394-413, 508-521, and 857-867 ka) recorded in a slope basin of the Nankai Trough subduction zone, off-shore Japan, which represents the major outcome of this study. The ages of the six landslides coincide mostly with interglacial periods. Thus, we propose that climate forcing might act as a preconditioning factor for slope instability in this active tectonic region.
\end{abstract}

Keywords: Mass transport deposit, Nankai Trough, $\delta^{18} \mathrm{O}$ isotope stratigraphy, Tephrochronology, Climate preconditioning

\section{Introduction}

Earthquakes are known to trigger submarine landslides in subduction zones, and these landslides can potentially amplify the generated tsunami wave (Kawamura et al. 2012; Strasser et al. 2013; Tappin et al. 2014), break strategically important undersea cable networks, and undercut structural foundations for oil and gas pipelines (Masson et al. 2006). However, not all recent megathrust earthquakes have produced large landslides (Henstock et al. 2006; Völker et al. 2011). In such regions, the recurrence of submarine landslides is lower than the earthquake frequency (Behrmann et al. 2014; Strasser et al. 2011), suggesting that earthquakes might represent the final trigger but not the main forcing mechanism for the generation of landslides in all regions. Nevertheless, in terms of mitigating hazards related to submarine

\footnotetext{
* Correspondence: katrina.kremer@sed.ethz.ch

${ }^{1}$ Geological Institute, ETH Zurich, Sonneggstrasse 5, 8092 Zürich, Switzerland ${ }^{2}$ Present address: Swiss Seismological Service, ETH Zurich, Sonneggstrasse 5, 8092 Zurich, Switzerland

Full list of author information is available at the end of the article
}

landslides, it is important to understand their frequency and causative factors.

Drill site C0018 of the Integrated Ocean Drilling Program (IODP) in the Nankai Trough was chosen to provide unprecedented long-term records of submarine landslides in a convergent margin setting (Fig. 1). Although this margin is characterized by magnitude $8+$ earthquakes occurring every $\sim 150$ years on average (Ando 1975), only six large landslide deposits (herein referred to as mass-transport deposits, MTDs) are recognized in the sedimentary record of drill site C0018 during the past $1 \mathrm{Ma}$ (Henry et al. 2012). In this region, repeated periods of intensified mass wasting lasting a few hundreds of thousands of years have coincided with pulses of enhanced tectonic activity along a margin-dominating out-of-sequence thrust (megasplay) (Strasser et al. 2009), where slope oversteepening, an extensional stress regime, and the lateral transmission of fluid overpressures may have preconditioned the slope sediments to fail (Ikari et al. 2011; Strasser et al. 2011). However, the age model of the sedimentary record is constrained solely by bio- and magnetostratigraphy and 


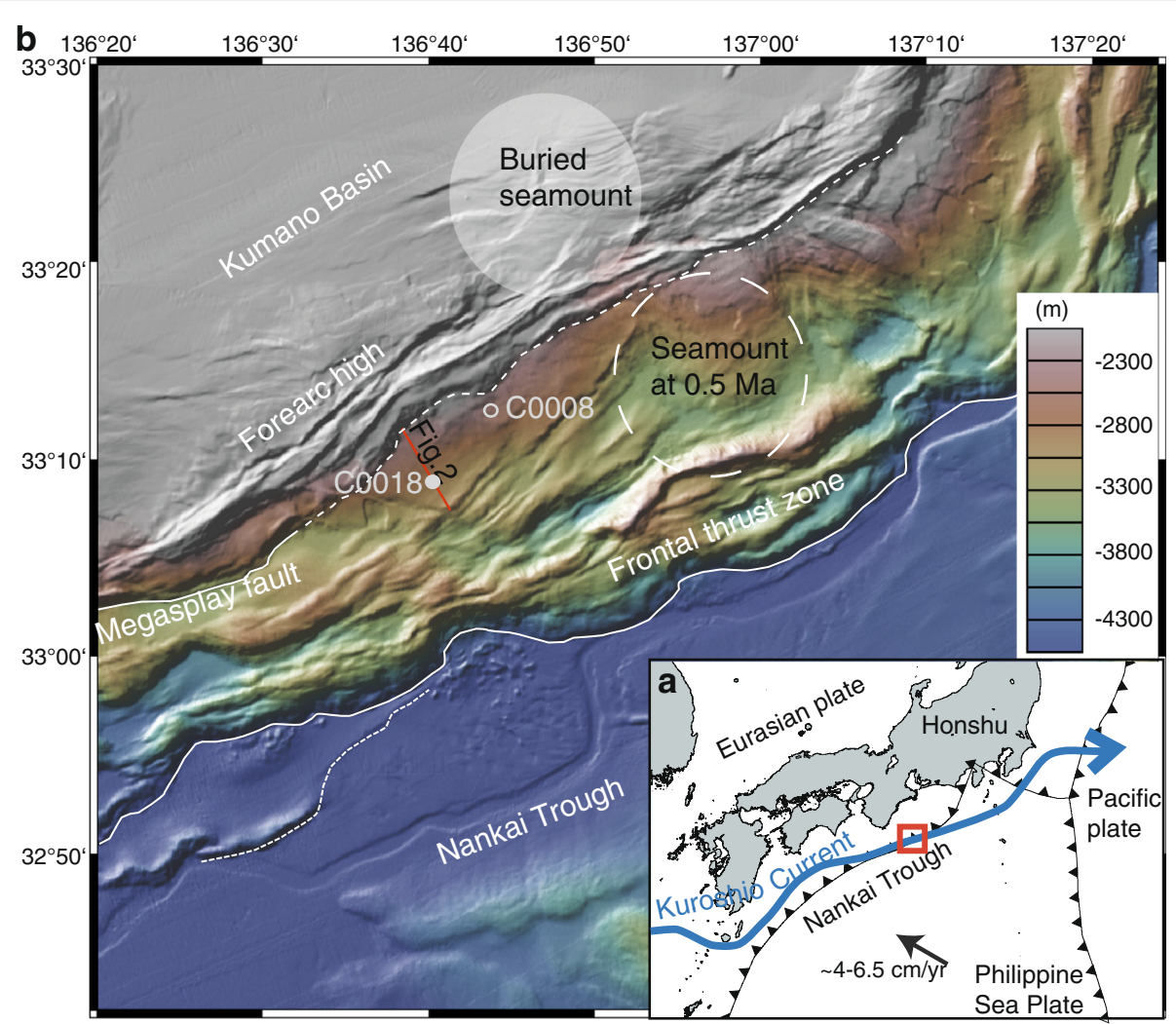

Fig. 1 Setting of the coring location in the Nankai accretionary wedge. a Overview map showing the subduction of the Philippine Sea Plate beneath the Eurasian Plate. The path of the Kuroshio Current is marked in blue. $\mathbf{b}$ Enlarged bathymetric map of the study site. C0018 (gray dot) is located in a basin downslope of the megasplay fault zone

two tephra ages (Ss-Az and Ss-Pnk) that date the emplacement of the oldest and largest MTD 6 to between 0.85 and 1.04 Ma (Henry et al. 2012). Thus, with the current age resolution, it is not possible to constrain the precise timing of individual MTDs, and we cannot resolve the complex interplay between tectonic and submarine landslides vs. other driving mechanisms such as climatic and oceanographic conditions that control sea-level change, sedimentation patterns, and gas hydrate stability. To better understand the preconditioning factors and triggers of submarine landslides in this highly active tectonic region, here, we present a long-term age model based on the $\delta^{18} \mathrm{O}$ isotope stratigraphy of planktonic foraminifera in combination with tephrochronology to date MTDs in the Nankai Trough.

\section{Regional setting and MTDs}

The Nankai Trough is a convergent plate boundary where the Philippine Sea Plate is subducting beneath the Eurasian Plate, southwest from the Japan coast, at a rate of 4.1-6.5 cm/year (Seno et al. 1993). A SE to NW transect (Kumano transect) across the region can be divided into six morphotectonic zones: trench, frontal thrust zone, imbricate thrust zone, megasplay fault zone, Kumano
Basin edge fault zone, and the forearc (Kumano) basin (Moore et al. 2009). The studied sediment sequence was retrieved from a slope basin located $\sim 3 \mathrm{~km}$ seaward of the outer forearc high, which constitutes a natural boundary between the Kumano forearc basin and the outer Nankai accretionary prism (Fig. 1; Henry et al. 2012; Strasser et al. 2011).

The basin is isolated from the shore, shelf, and forearc basin, and water depth reaches $\sim 3000 \mathrm{~m}$. This basin represents the depocenter of downslope mass transport from the forearc high and megasplay fault zone (Figs. 1 and 2), as imaged by 3D seismic reflection data (Henry et al. 2012; Strasser et al. 2011). Acoustically transparent to chaotic facies with truncated reflections at the base are interpreted as MTDs that occur within the upper seismic unit 1a (SU1a; Fig. 2).

Within seismic unit 1b (SU1b), low-amplitude wedges and layers thinning out toward the basin flanks are also interpreted as MTDs. The MTDs imaged in the seismic reflection data show thicknesses of between 20 and $50 \mathrm{~m}$ and extend laterally over several kilometers along strike (Strasser et al. 2011). Site C0018 was drilled where the MTDs wedge out, and basal erosion by the MTDs is minimal (Henry et al. 2012). The $\sim 300 \mathrm{~m}$ 


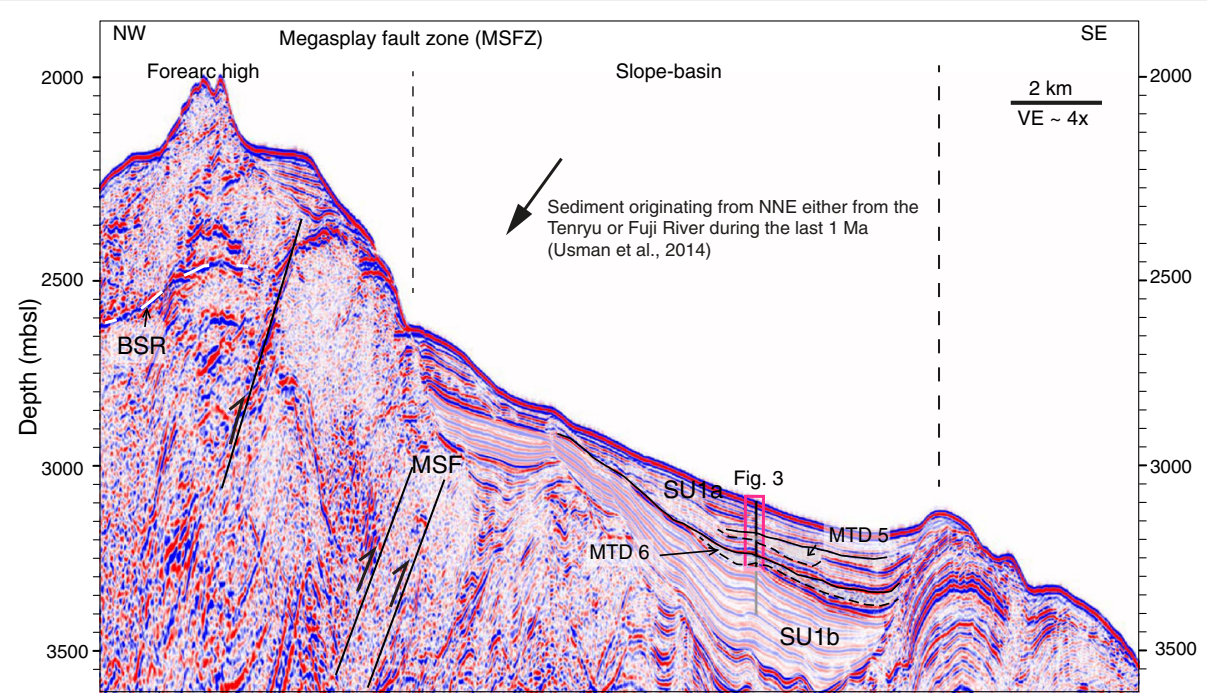

Fig. 2 Seismic reflection profile showing the stratigraphic succession of the lower slope basin downslope of the forearc high and the megasplay fault zone (MSF). The multiple stacked MTD features (dashed black lines represent the bases of MTDs, continuous black lines the tops of the MTDs) can be identified on the seismic reflection profile. Bottom-simulating reflector (BSR; white dashed line) is indicative of the occurrence of gas hydrate-laden sediments. Site C0018 (black bar) is located within the slope basin. SU1a seismic unit 1a, SU1b seismic unit b (white transparent area marks the limits of SU1b)

thick sediment sequence drilled at C0018 is subdivided into two lithological units (U1a and U1b) that correlate with seismic units SU1a and SU1b, respectively, (Figs. 2 and 3; Strasser et al. 2012). U1a corresponds to the upper Pleistocene sediments that are $\sim 200 \mathrm{~m}$ thick (Fig. 3) and is composed of bioturbated hemipelagic mud with subhorizontal and SE-dipping volcanic ash layers that are a few centimeters thick, and is intercalated with a succession of six MTDs (MTD 1 to MTD 6; Fig. 3; Henry et al. 2012; Strasser et al. 2012). The MTDs are recognized based on their chaotic pebbly and/or mixed lithologies with inclined layers and shear zones (Henry et al. 2012; Strasser et al. 2012). The tops of MTDs 1, 2, and 6 are well defined and, in the cases of MTDs 2 and 6, marked by an overlying turbidite (Fig. 4; Strasser et al. 2012). X-ray computed tomography (X-CT) images were used to identify the bases of the MTDs (Strasser et al. 2012). Lineations formed by pyrite mineralization/concretions and low discontinuities associated with increased X-CT values are interpreted as shear zones. These shear zones represent the bases of MTDs 2, 3, and 5 (Strasser et al. 2012). The thicknesses of the MTDs within the U1a section vary from 0.5 to $61 \mathrm{~m}$, with a cumulative thickness of $98 \mathrm{~m}$ (Table 1).

The lowermost $100 \mathrm{~m}$ of lithological unit U1b is composed of hemipelagic sediment intercalated with turbidites and tephra layers of millimeter to centimeter scale. No MTD-features are recognized in U1b. Our study focusses on the upper $200 \mathrm{~m}$ of lithological unit U1a.

\section{Methods/Experimental}

\section{Radiocarbon dating}

Five planktonic foraminifera samples were extracted from the sediments of $\mathrm{C} 0018$ (between 0.2 and $1.4 \mathrm{~m}$ depth; Table 2) for radiocarbon dating. Four samples were taken from the hemipelagic sediments overlying MTD 1 while sample ETH-59792 was taken from sediments of MTD 1 (Table 2; Fig. 5). As the sampled material from MTD 1 is interpreted as redeposited sediments, the age of sample ETH-59792 is assumed to be too old and was thus excluded from the age-depth model.

The ${ }^{14} \mathrm{C}$ ages were calibrated using the calibration curve Marine13.14C (Reimer et al. 2013) and a ${ }^{14} \mathrm{C}$ reservoir age of 109 (standard deviation of 84) years (average value calculated from the nearest reference sites of Shishikura et al. 2007; Yoneda et al. 2007).

\section{Tephrochronology}

We sampled and analyzed tephra layers in thin sections to determine the composition and shape of glass shards. Major element compositions of volcanic glass shards were determined using an energy dispersive spectroscopy (EDS)-type EPMA at Fukushima University, Japan. An INCA $x$-act EDS system was attached to a JSM5800LV scanning electron microscope. Operating conditions were $15 \mathrm{kV}$ accelerating voltage, $0.3 \mathrm{nA}$ electric current on a faraday cup, and $5 \mu \mathrm{m} \times 5 \mu \mathrm{m}$ beam scanning area (Nagahashi et al. 2003). A geographically representative spread of volcanic glass chemistry for the past $5 \mathrm{Ma}$ is reported in numerous land-based 


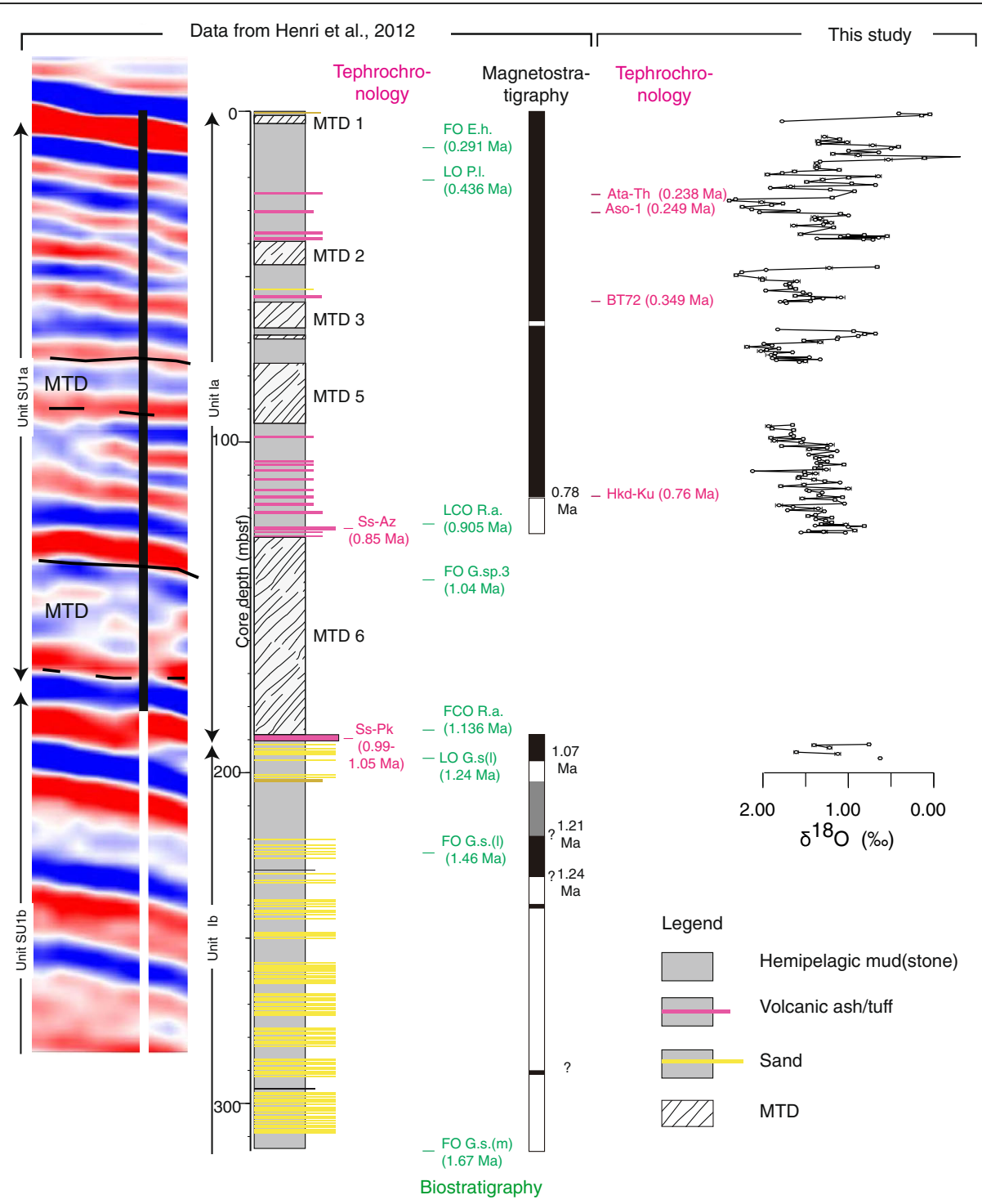

Fig. 3 Correlation of seismic data with core C0018. Data from previous studies are shown, including lithology and dating of C0018 based on magnetostratigraphy, nannofossil biostratigraphy, and tephrochronology (Ss-Az and As-Pnk) from lithological unit U1a (Henry et al. 2012). Data from this study include $\delta^{18} \mathrm{O}$ data and tephrochronology (Ata-Th, Aso-1, BT72, and Hkd-Ku)

tephra studies (e.g., Kimura et al. 2015; Nagahashi et al. 2004, 2015). Using these correlations, we obtained the relative ages of tephra layers from site $\mathrm{C} 0018$ (Table 3; Fig. 6). The tephrochronology is used to establish an initial age-depth model of lithological unit U1a in C0018A.

\section{Oxygen isotope stratigraphy}

$\delta^{18} \mathrm{O}$ oxygen isotope compositions were measured on planktonic foraminifera (Globigerina inflata) handpicked from hemipelagic sediments of $\mathrm{C0018}$ at sampling steps of around $50 \mathrm{~cm}$ and considering the fraction between 125 and $350 \mu \mathrm{m}$. The isotopic composition was measured according to the method described by
Breitenbach and Bernasconi (2011). Briefly, 100-200 $\mu \mathrm{g}$ of foraminiferal calcite tests was placed in $12 \mathrm{ml}$ Exetainers (Labco, High Wycombe, UK) and flushed with pure helium. The samples were reacted with 3-5 drops of $100 \%$ phosphoric acid at $70{ }^{\circ} \mathrm{C}$ with a ThermoFisher GasBench II device connected to a ThermoFisher $>$ Delta $\mathrm{V}$ mass spectrometer. The average $<$ ?A3B2 thyc $=-$ long-term reproducibility of the measurements, based on repeated analyses of standards, was $\pm 0.05 \%$ o for $\delta^{13} \mathrm{C}$ and $\pm 0.06 \%$ for $\delta^{18} \mathrm{O}$. The instrument was calibrated with the international standards NBS19 $\left(\delta^{13} \mathrm{C}\right.$ $=1.95$ and $\left.\delta^{18} \mathrm{O}=-2.2 \%\right)$ and NBS18 $\left(\delta^{13} \mathrm{C}=-5.01\right.$ and $\delta^{18} \mathrm{O}=-23.01 \%$ ). The isotope values are reported in conventional delta notation with respect to 

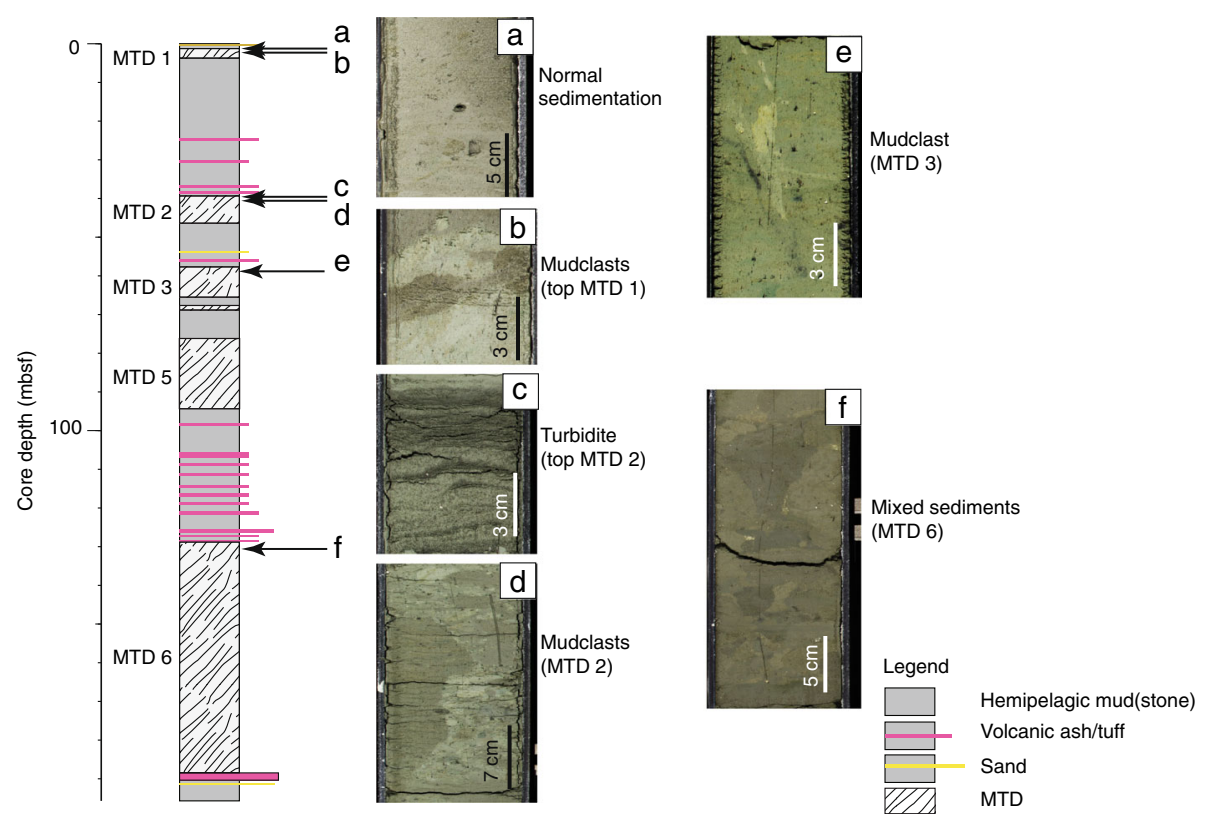

Fig. 4 Examples of sedimentological features of the hemipelagic sediment (a) and of various parts of the MTDs (such as mudclasts in $\mathbf{b}$, $\mathbf{d}$ and $\mathbf{e}$; turbidites in $\mathbf{c}$ and mixed sediments in $\mathbf{f}$ )

VPDB (Vienna Pee Dee Belemnite). The generated $\delta^{18} \mathrm{O}$ curve was then correlated to the LR04 stack isotope reference curve (Lisiecki and Raymo 2005) and the dataset of Bassinot et al. (1994).

\section{Age-depth model}

The age-depth model was constructed by linear interpolation of neighboring samples using the clam code (Blaauw 2010) from the open source statistical software "R." The ${ }^{14} \mathrm{C}$ dates and tephrochronology were used to establish an initial age-depth model in order to express the $\delta^{18} \mathrm{O}$ curve of $\mathrm{C} 0018 \mathrm{~A}$ as a function of time and to compare the isotope data with the LR04 stack reference curve of Lisiecki and Raymo (2005) and the stack isotope curve of Bassinot et al. (1994). The Bassinot et al. (1994) dataset has been used in previous studies to date these tephras (see references in Table 3). This comparison enables the definition of four matching points (X1-X4; Fig. 7), while the ages of the matching points are subsequently taken from the LR04 reference curve and attributed to peaks at C0018A. The input data used for this age model are summarized in Table 4.

To establish the age-depth model, we expressed the depth as MTD-corrected depth. The MTDs are considered to be redeposited sediments from the slopes and therefore might repeat parts of the $\delta^{18} \mathrm{O}$ sequence. This assumption might be incorrect for the very large MTDs 5 and 6 . The bases of these MTDs are characterized on

Table 1 Summary of lithological features characterizing MTDs at site C0018

\begin{tabular}{|c|c|c|c|c|c|}
\hline MTD & Thickness (m) & Top (m) & Bottom (m) & MTD-corrected depth (m) & Characteristics \\
\hline MTD 1 & 2.9 & 1.4 & 4.3 & 1.4 & Mudclast bearing sediments and convolute bedding \\
\hline MTD 2 & 7.3 & 39.5 & 46.7 & 36.5 & $\begin{array}{l}\text { Coherent bedding bounded by shear zones and topped by } 8 \mathrm{~cm} \\
\text { thick turbidite }\end{array}$ \\
\hline MTD 3 & 7.7 & 58.0 & 65.7 & 47.8 & $\begin{array}{l}\text { Mixed sediments and a } 2 \mathrm{~mm} \text { thick clay layer as potential shear zone } \\
\text { at the base }\end{array}$ \\
\hline MTD 4 & 0.5 & 66.4 & 66.9 & 48.8 & $\begin{array}{l}\text { Fluidized ash layer as primary structure but deformation due to coring } \\
\text { disturbance and gas expansion cannot be excluded }\end{array}$ \\
\hline MTD 5 & 18.5 & 75.9 & 94.4 & 58.1 & $\begin{array}{l}\text { Mixed sediments, mud clasts, convolute bedding, tilted strata with a } \\
\text { sharp lower boundary }(X-C T) \text { as shear zone at the base }\end{array}$ \\
\hline MTD 6 & 61.0 & 127.6 & 188.6 & 91.2 & $\begin{array}{l}\text { Chaotic and convolute bedding and mixing of ash with hemipelagic } \\
\text { deposits intercalated with coherently bedded sediments; shear zones } \\
(\mathrm{X}-\mathrm{CT} \text { ) cannot be associated to the base; the base is defined as the top } \\
\text { of underlying ash layer; } 8 \mathrm{~cm} \text { thick turbidite as upper boundary }\end{array}$ \\
\hline
\end{tabular}


Table 2 Radiocarbon ages obtained for foraminiferas (Globigerina inflata). Calibration was performed with the "calibrate" function of the clam code (Blaauw 2010) from the open-source statistical software " $\mathrm{R}$ " using the marine calibration curve Marine13.14C (Reimer et al. 2013). A reservoir age of 98 years was used

\begin{tabular}{llcll}
\hline Sediment core depth $(\mathrm{m})$ & Laboratory no. & Conventional radiocarbon age ${ }^{14} \mathrm{C}$ year BP & 2 sigma calibration year cal BP & Dated material \\
\hline 0.20 & ETH-50925 & $4565 \pm 88$ & $4415-4826$ & Planktonic foraminifera \\
0.49 & ETH-50926 & $4919 \pm 84$ & $4862-5292$ & Planktonic foraminifera \\
0.72 & ETH-50927 & $7183 \pm 88$ & $7411-7715$ & Planktonic foraminifera \\
1.09 & ETH-59791 & $9980 \pm 85$ & $10600-11066$ & Planktonic foraminifera \\
1.48 & ETH-59792 & $21760 \pm 225$ & $25121-25970$ & Planktonic foraminifera \\
\hline
\end{tabular}

the seismic reflection profile by truncated upramping reflections, indicating that the landslide partly eroded the sedimentary succession of the lower basin within its depositional area (Strasser et al. 2011), and incorporated it into the landslide deposit. Thus, the thicknesses of MTDs 5 and 6 might incorporate "in situ" sediments at their base. Consequently, sediment sections may be missing in the continuous sedimentary record at the base of MTDs 5 and 6. However, based on lithology, the thickness of these in situ remobilized sediments cannot be defined. As the dating of MTD 6 is based on the two tephra layers Hdk-Ku and Ss-Az, this remobilization does not affect the estimated age of MTD 6 (Fig. 7).

\section{Results and discussion}

Tephrochronology

Based on the geochemical composition of the sampled tephras at C0018 and comparison with on-land tephras, the ages of the tephras were determined (Fig. 6;

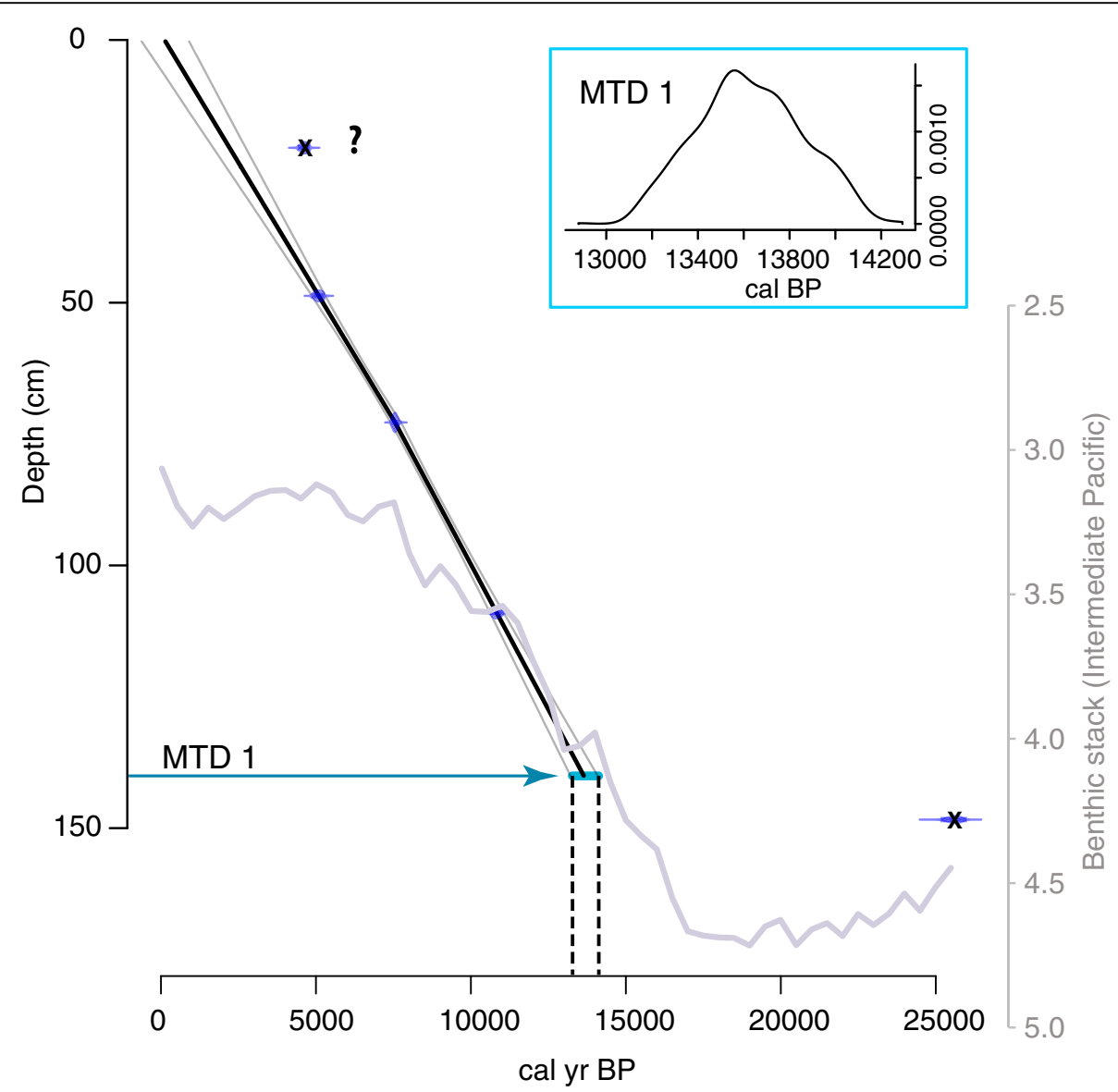

Fig. 5 Age model of MTD 1. Calibrated age intervals are indicated with 95\% probability (Table 1). The gray envelope shows the $95 \%$ confidence interval, giving an extrapolated age of 13,000-14,200 year cal BP for MTD 1. The inset represents the age probability of MTD 1. The gray curve refers to the $\delta^{18} \mathrm{O}$ values of benthic foraminifera of the stacked curve, representative of the intermediate Pacific (Stern and Lisiecki 2014) 
Table 3 Tephra ages used as time references for $\delta^{18} \mathrm{O}$ isotope stratigraphy. The estimated age, method of age determination, and references are given for each tephra age

\begin{tabular}{llll}
\hline Tephra name & Estimated age (Myr) & Method & References \\
\hline Ata-Th & 0.238 (MIS 8.0) & $\begin{array}{l}\text { Comparison of pollen and diatom records on the Lake Biwa } \\
\text { sediments with marine oxygen isotopic records }\end{array}$ & (Kuwae et al. 2002; Nagahashi et al. 2004) \\
Aso1 & 0.249 (MIS 8.2) & $\begin{array}{l}\text { Comparison of pollen and diatom records on the Lake Biwa } \\
\text { sediments with marine oxygen isotopic records } \\
\text { BT72 }\end{array}$ Comparison of pollen and diatom records on the Lake Biwa & (Kuwae et al. 2002; Nagahashi et al. 2004) \\
Hkd-Ku & 0.74 (MIS 10.3) $19.1-18.4)$ & $\begin{array}{l}\text { Comprehensive estimation of the Fission track age, K-Ar and } \\
\text { stratigraphy of the Osaka Group }\end{array}$ & (Nagahashi et al. 2015; Suzuki et al. 2005) \\
SS-Az & 0.85 & Biostratigraphy, isotope stratigraphy & (Pickering et al. 1999; Hayashida et al. 1996)
\end{tabular}

Table 3). Tephras Ata-Th (0.238 Ma; Kuwae et al. 2002; Nagahashi et al. 2004), Aso-1 (0.249 Ma; Kuwae et al. 2002; Nagahashi et al. 2004), BT72 (0.349 Ma; Kuwae et al. 2002; Nagahashi et al. 2004), and Hkd-Ku (0.76 Ma; Nagahashi et al. 2015; Suzuki et al. 2005) occur at depths of 24.9, 29.2, 57.1, and $114.3 \mathrm{~m}$, respectively, (22.02, 26.4, 46.9, and $77.9 \mathrm{mf}$ MTD corrected depth, respectively).

\section{$\delta^{18} \mathrm{O}$ isotope stratigraphy}

Oxygen isotope values of $\mathrm{C} 0018$ for the studied sequence (upper $200 \mathrm{~m}$ of C0018A) range between -0.31 and $2.39 \%$. While the uppermost $75 \mathrm{~m}$ of C0018A shows high variability in $\delta^{18} \mathrm{O}$ data, with values between minima of around $1 \%$ and maxima of $2.5 \%$, the lowermost $100 \mathrm{~m}$ display a more regular pattern (Fig. 2). For the lower part, a comparison of the $\mathrm{C} 0018 \mathrm{~A} \delta^{18} \mathrm{O}$ dataset with the stack reference curves is not straightforward because of the difference in $\delta^{18} \mathrm{O}$ values between the planktonic and benthic foraminifera datasets. However, we observe broadly similar patterns between the two curves and therefore compare the trends between warm and cold phases.

\section{Age-depth model and dating of MTDs}

The final age-depth model of C0018A is based on ${ }^{14} \mathrm{C}$ age data, tephrochronology, and isotope stratigraphy. The matching points (X1-X4) are dated at 125, 135, 328 , and $400 \mathrm{ka}$ on the LR04 reference curve, respectively (Fig. 7, before matching). The matching between peaks of C0018A and LR04 is based on visual correlation with uncertainties of $\sim 5000$ years due primarily to the sampling interval in C0018A. The uncertainties related to the tephrochronology can be up to several tens of thousands of years (e.g., Hkd-Ku; Suzuki et al. 2005). To take these uncertainties into account, we introduced an average error of $\sim 2000$ years for the tephras (Table 4). A comparison between the reference datasets of Lisiecki and Raymo (2005) and Bassinot et al. (1994) shows several offsets in the isotope stratigraphy.

The ages of the MTDs can be extracted from the agedepth model. MTD 1 is essentially based on the results of radiocarbon dating and is dated to 13.0-14.2 cal kyr BP (Fig. 5).

The ages of MTDs 2, 3, 4, and 5 are based on tephrochronology and isotope stratigraphy and are dated at 323-339, 372-384, 394-413, and 508-521 kyr, respectively (Fig. 8). The age of MTD 6 is based on sedimentation rates calculated between $\mathrm{Hkd}-\mathrm{Ku}$ and $\mathrm{Ss}-\mathrm{Az}$ and yield an age of 857-867 kyr.

Furthermore, MTD 1, which is dated at 13.0-14.2 kyr cal BP, can be placed within a phase of decreasing $\delta^{18} \mathrm{O}$ values (Fig. 7). The onset of the termination of the last glacial cycle has been dated at $\sim 16.5 \mathrm{kyr}$ BP in the Intermediate Pacific (Stern and Lisiecki 2014). Thus, MTD 1 can be placed within Marine Isotope Stage 1 (MIS 1) (Fig. 7). The decreasing trend in $\delta^{18} \mathrm{O}$ values above MTD 1 (from 4.7 to $3.2 \%$ ) correlates with the trend in $\delta^{18} \mathrm{O}$ values of the Intermediate Pacific (Stern and Lisiecki 2014). Thus, MTD 1 can be placed within the warming trend of MIS 1 (increases in temperature and sea level), and it occurred $2000-3000$ years after the onset of MIS 1. Similarly, MTDs 2 and 6 can be placed within the warming trends of MIS 9 and 21, respectively. MTD 5 can be placed within the phase of decreasing $\delta^{18} \mathrm{O}$ values of MIS 13 , while MTDs 3 and 4 are also placed within an interglacial (MIS 11), albeit not within the transition to heavier $\delta^{18} \mathrm{O}$ values. Although uncertainties of around 10,000-20,000 years exist, the dating of C0018A provides a better constraint on the timing of the MTD. Furthermore, the use of the isotope stratigraphy illustrates that the MTDs are all placed within odd-numbered marine isotope stages, thus raising the possibility of a climatic influence on the preconditioning of MTD-related slope failures.

\section{Climate as a preconditioning factor?}

The data of the present study show that the MTDs recorded at site C0018 in the slope basin of the Nankai accretionary prism occur within interglacials, suggesting that the MTDs were emplaced during phases of relative high sea level and temperatures. This implicates the role of climate as a primary preconditioning factor for slope 

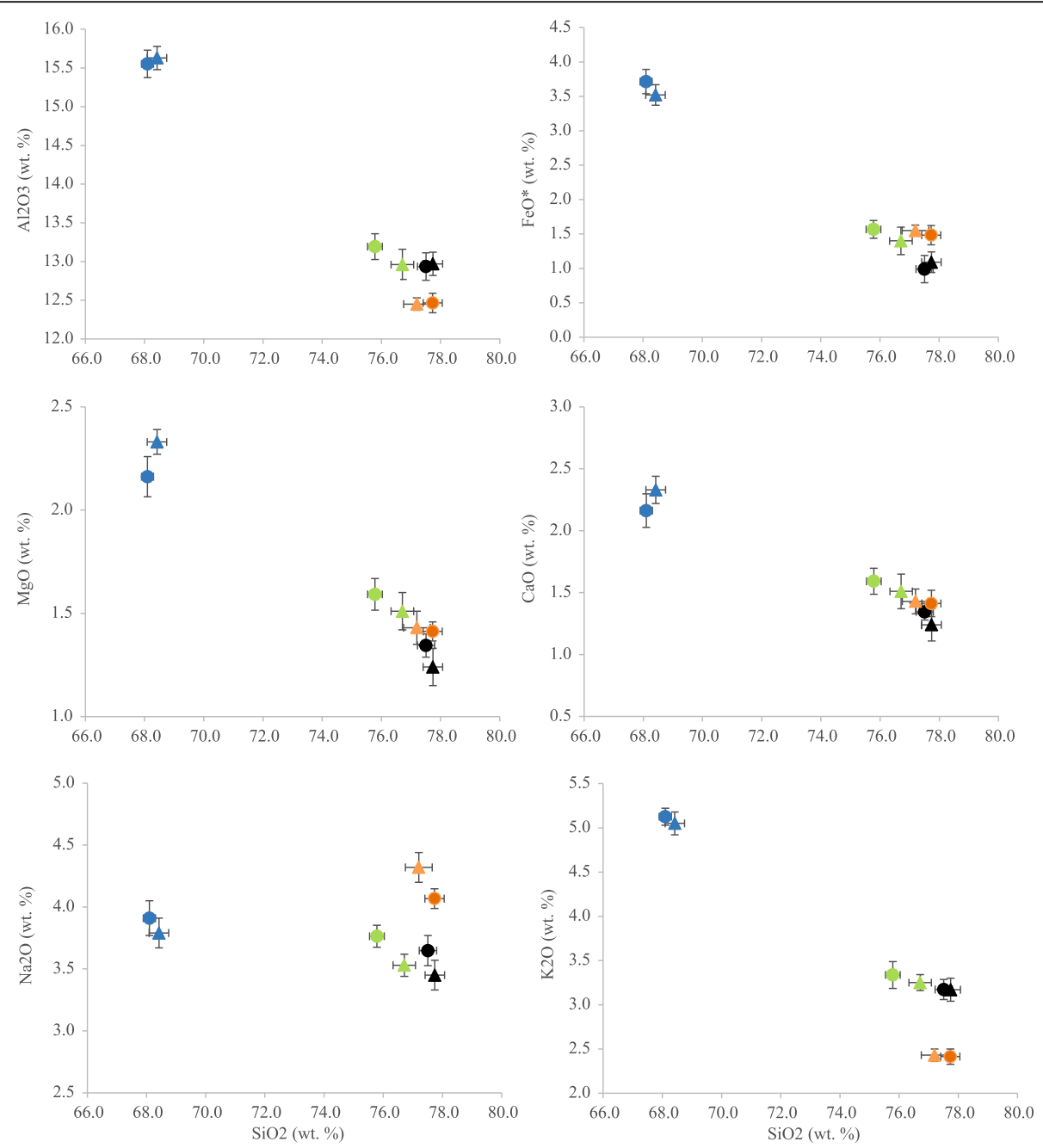

$$
\begin{aligned}
& \text { C0018 Reference } \\
& \text { - } 03 \mathrm{H} 9-0 \text { ॥ Ata-Th* } \\
& \text { - 04H3-81 } \Delta \text { Aso-1* } \\
& \text { 07H3-37 } \triangle \mathrm{BT} 72 * \\
& \text { - } 13 \mathrm{H} 9-87 \triangle \mathrm{Hkd}-\mathrm{Ku}^{* *}
\end{aligned}
$$

Fig. 6 Major oxide compositions of on-land reference tephras and tephras in C0018. The data of the on-land tephras (Table 3; Hayashida et al. 1996; Kuwae et al. 2002; Nagahashi et al. 2004, 2015; Suzuki et al. 2005; Yoshikawa and Mitamura 1999) are marked by triangles, and data of the c0018-tephras are marked by circles. Matching tephras are highlighted by the same color. Error bars represent one standard deviation

failures in this highly active tectonic region. If we assume the result to be representative, it is necessary to discuss this possible relationship. As numerous articles have discussed the relationship between climate and submarine landslides (e.g., Owen et al. 2007; Maslin et al. 2010), here, we consider the climate-influenced factors (e.g., sea level, water temperature, and related factors such as gas hydrate destabilization and sedimentation rates) that could precondition slope failures and only briefly discuss how these factors may be applicable in the studied setting. The discussion will mainly focus on the example of MTD 1 in the context of the last interglacial cycle.

\section{Sea level changes}

Rising sea level during interglacial periods results in enhanced water loading on continental margins and overpressure in sediments. This has been suggested as a trigger for the Holocene Storegga Slide and tsunami (e.g., Smith et al. 2013). The timing of MTD 1 coincides with a concentration of passive margin deposits aged between 8 and $15 \mathrm{kyr}$ (Brothers et al. 2013). Following 


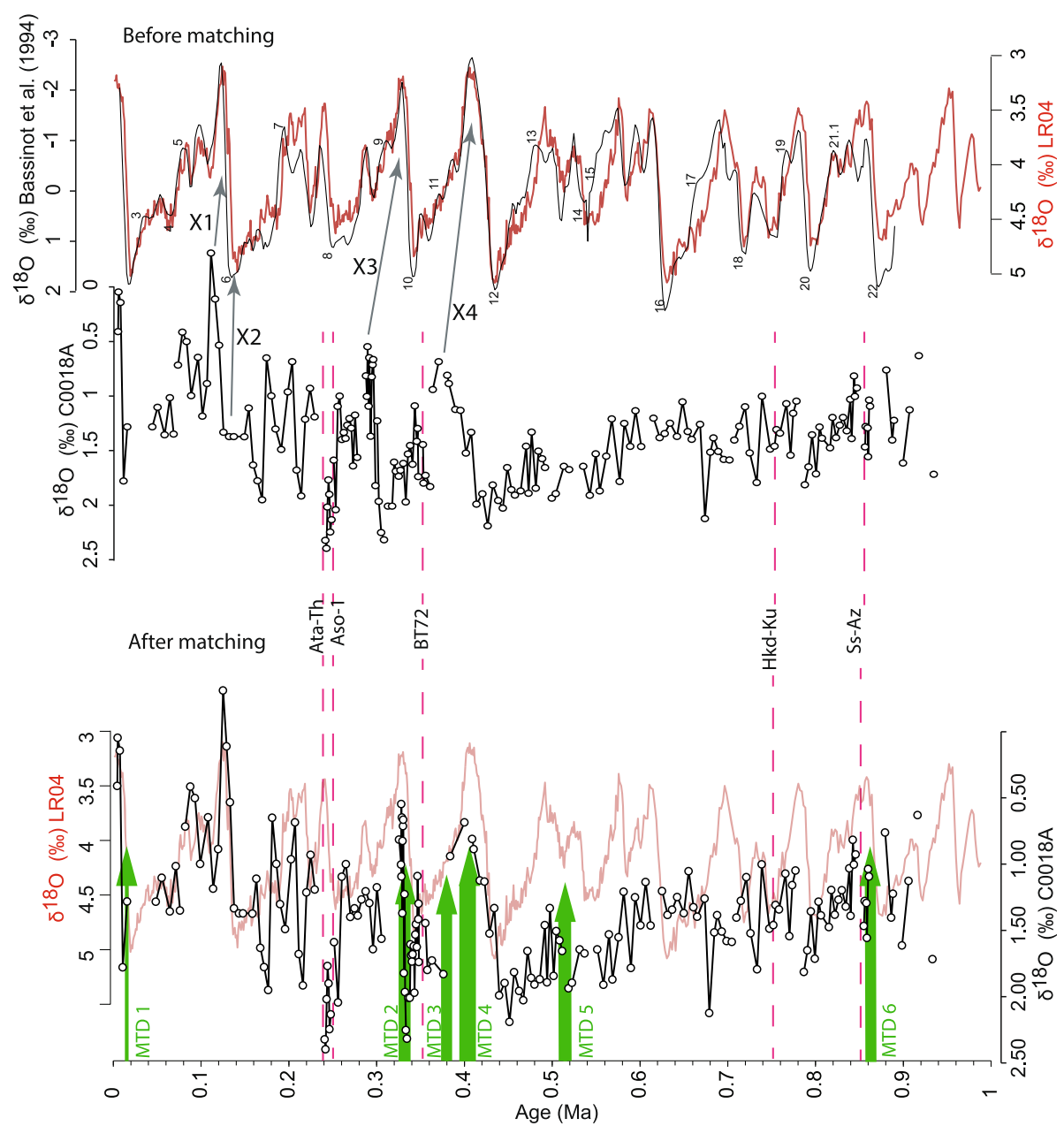

Fig. 7 Core $\operatorname{Co018} \delta^{18} \mathrm{O}$ profile as a function of age based on tephrochronology and the LR04 stack (Lisiecki and Raymo 2005) before and after matching. The dataset from Bassinot et al. (1994) is shown in black. The gray arrows between the two curves indicate the timing of the matching points (X1-X4). The pink dotted lines indicate the dated tephras used as time markers for the correlation. Green arrows indicate MTDs. MIS stages are from Bassinot et al. (1994)

Brothers et al. (2013), the eustatic sea level rise during this phase had the potential to cause bending stresses that could lead to enhanced seismicity, thereby establishing a direct relationship between sea level rise and slope failure on passive margins. However, Urlaub et al. (2013) instead showed that the ages of landslides on passive margins can be described by a temporally random Poisson distribution and therefore do not show a positive correlation between the frequency of major slope failures on passive margins and sea level during the past 180,000 years. Thus, it would be speculative to state that glacial-to-interglacial sea-level variations caused the slope failures of the present study.

\section{Temperature and gas hydrates}

Changes in water temperature may alter the stability of gas hydrates. Furthermore, large amounts of gas hydrates have been detected in the present study region
(Bangs et al. 2010) and at drilling site C0008, located directly in the upslope region of our studied MTD site (Kinoshita et al. 2011; Fig. 1), as indicated by the presence of a bottom-simulating reflector (BSR) in seismic data (Fig. 2) and chemical anomalies in the borehole (Kinoshita et al. 2011), respectively. Most of the 250$350 \mathrm{~m}$ thick sedimentary succession overlying the accretionary prism is currently located within the stability zone of gas hydrate. However, during glacial terminations, bottom-water temperature can increase by as much as $2{ }^{\circ} \mathrm{C}$, as documented in the deep waters of the western Pacific (Siddall et al. 2010). Indeed, a theoretical methane hydrate stability calculation (Sloan and Koh 2008), assuming a $2{ }^{\circ} \mathrm{C}$ increase in bottom-water temperature, diffusive heat transport through sediments, and an average heat flow $60 \mathrm{~mW} / \mathrm{m}^{2}$ (Yamano et al. 2014), indicates that changes in bottom-water temperatures can result in an upward shift of the gas hydrate 
Table 4 Summary of input data for the age-depth model shown in Fig. 8

\begin{tabular}{|c|c|c|c|c|c|}
\hline Sample ID & C14 age & Cal BP & Error & Reservoir age & MTD-corrected depth (m) \\
\hline ETH-50925 & 4564.89 & & 87.53 & 109 & 0.2045 \\
\hline ETH-50926 & 4919.91 & & 83.9 & 109 & 0.4865 \\
\hline ETH-50927 & 7183.19 & & 88.305 & 109 & 0.7275 \\
\hline ETH-59791 & 9980 & & 85 & 109 & 1.09 \\
\hline ETH-59792 & 21760 & & 225 & 109 & 1.484 \\
\hline $\mathrm{X} 1$ & & 125000 & 5000 & 0 & 10.27 \\
\hline$x_{2}$ & & 135000 & 5000 & 0 & 12.663 \\
\hline Ata-Th & & 238000 & 2000 & 0 & 22.028 \\
\hline Asol & & 249000 & 2000 & 0 & 26.355 \\
\hline X3 & & 328000 & 5000 & 0 & 34.37 \\
\hline BT72 & & 349000 & 2000 & 0 & 46.89 \\
\hline X4 & & 400000 & 5000 & 0 & 48.491 \\
\hline $\mathrm{Hkd}-\mathrm{Ku}$ & & 750000 & 2000 & 0 & 77.893 \\
\hline Ss-Az & & 850000 & 2000 & 0 & 89.784 \\
\hline
\end{tabular}

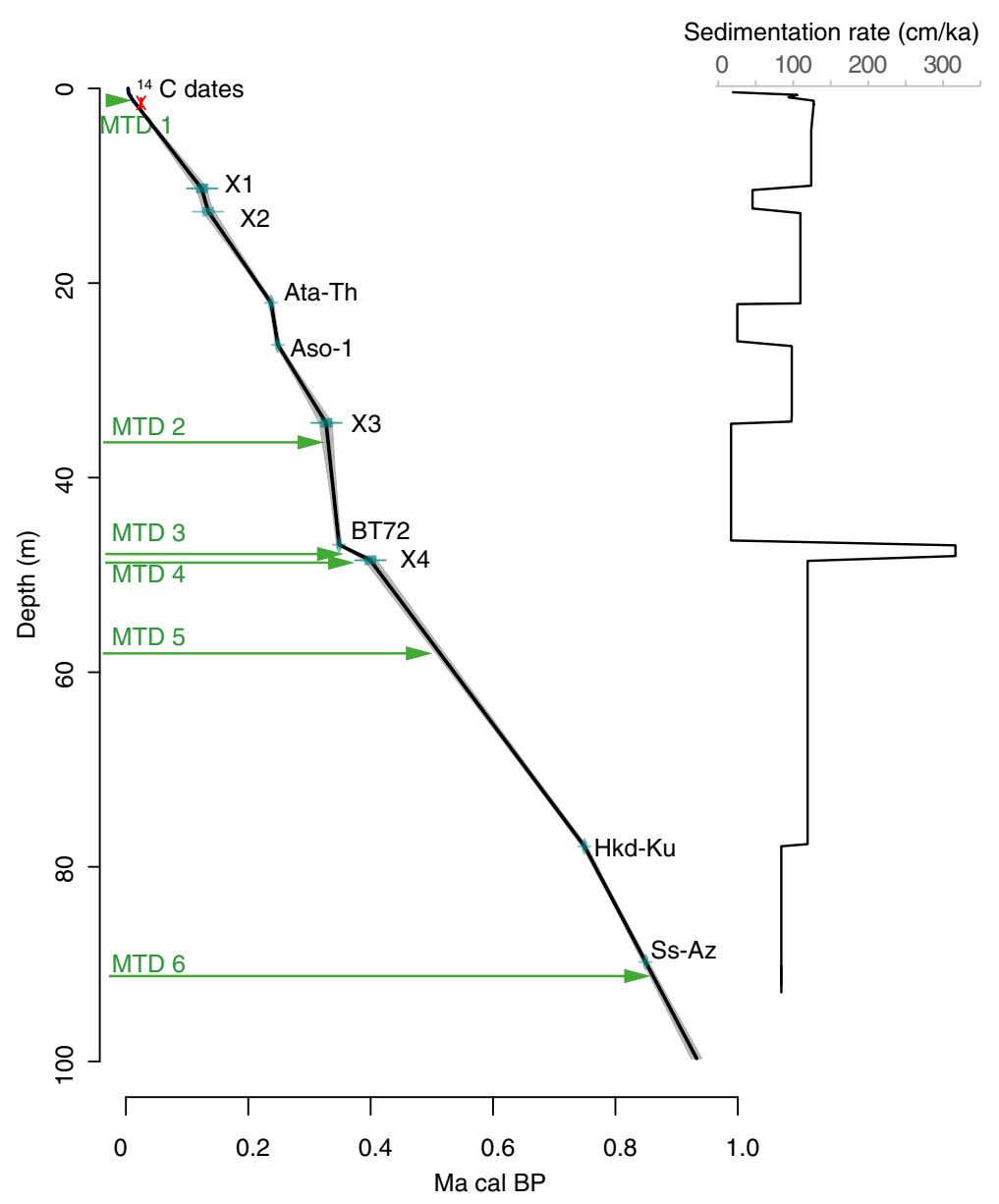

Fig. 8 Age-depth model and profile of sedimentation rates at C0018A based on ${ }^{14} \mathrm{C}$ dates from the top of the drill core, tephrochronology, and matching points $\left(X_{1}-X_{4}\right)$ used for correlation of the $\delta^{18} \mathrm{O}$ values of C0018A and the stack reference curve LR04. The depth of the MTD is also shown 
stability zone by up to $11 \mathrm{~m}$ over 10,000 years. This may result in hydrate dissociation, producing weak zones within sediments and therefore initiating or preconditioning slope failure (Sultan et al. 2004). In contrast, increasing pressure at the seafloor due to rising sea level would shift the base of the hydrate stability zone downward.

The Kuroshio Current off Japan is one of the strongest warm currents in the northwest Pacific Ocean (Iwatani et al. 2016; Fig. 1), as it transports heat northward from the tropics. The Kuroshio Current might therefore play an important role in increasing bottom-water temperatures in the study region. However, sea surface temperature (SST) reconstructions have shown that the area south of Japan was occupied by cold water masses during the period between the LGM and the start of the Holocene (Ikehara et al. 2011 and references therein), associated principally with a southward shift of the Kuroshio path during the last glaciation-deglaciation (Sawada and Handa 1998). Thus, sea surface temperatures were lower at the time of MTD 1.

\section{Sedimentation rates}

During glaciations and associated relative sea-level lowstands, sediment delivery to slopes is expected to be higher, thus possibly causing unstable slopes (Brothers et al. 2013). IODP drill site C0018 is separated from the shore, shelf, and upper slope areas by the morphologic high of the megasplay fault and only receives remobilized sediments from slopes that are susceptible to fail at water depths of 2000-2500 m (Figs. 1 and 2). There is no direct sediment source into the basin and the main depocenters nearby are located in the Kumano basin and downslope in the Nankai Trough (Buchs et al. 2015; Usman et al. 2014). There is possibly sediment input from the NNE, from the Tenyu or Fuji rivers (Usman et al. 2014), but as the sediments deposited in the studied basin are very fine grained, this represents only the very distal to pelagic part of the supplied sediment. The sedimentation rates at C0018A determined in this study vary by $\sim 100 \mathrm{~cm} / \mathrm{kyr}$ (which is the same order of magnitude as estimated by Henry et al. 2012). A significant increase in sedimentation rate is only observed before MTDs 3 and 4 of up to $300 \mathrm{~cm} / \mathrm{kyr}$. Thus, although the basin is isolated, we cannot exclude the possibility that sediment availability does not influence MTD occurrence. However, the exact timing of this change is not well constrained by the age model, as the sedimentation rate is based on linear interpolation between neighboring dating points.

Overall, this discussion has shown that the data are not sufficient to explicitly determine how climate is affecting slope stability. In particular, MTDs at C0018A do not coincide with every interglacial during the past $1 \mathrm{Ma}$. Thus, further studies are needed to better understand the preconditioning of mass movements.

\section{Climate vs. local effects vs. tectonic factors}

As mentioned above, MTDs at C0018 do not coincide with every interglacial during the past $1 \mathrm{Ma}$. However, we have to consider that $\mathrm{C} 0018$ does not record all MTDs of the slope basin, as the source and deposition of MTDs might vary through time (e.g., Yamada et al. 2010). Thus, C0018 may not be fully representative of the entire basin. However, as the 3D reflection seismic data in the region around C0018 do not image any other thick MTDs (Strasser et al. 2011), C0018 might therefore be representative in terms of its ability to capture the largest MTD events, although we cannot exclude the potential for lower-volume, higher-frequency MTDs that cannot be resolved in the seismic data. If we assume that, at least for the large landslides, C0018 is representative of the entire basin, the data suggest that MTDs within odd-numbered marine isotopic stages occur during three phases (MTD 1 at 13-14.2 cal kyr, MTDs 2-5 between 0.3 and $0.5 \mathrm{Ma}$, and MTD 6 at $0.86 \mathrm{Ma}$ ). The first MTD (MTD 6) occurs close to the end of a period of major tectonic uplift of the forearc high between 0.9 and $1.3 \mathrm{Ma}$ (Gulick et al. 2010). This uplift resulted in slope steepening, thereby creating the slopes necessary for the initiation of slope failure and perhaps explaining the onset of mass transport deposition at $\sim 0.86 \mathrm{Ma}$ with MTD 6 . For the period around $0.5 \mathrm{Ma}$, as inferred from the reconstructed flow directions of MTDs and bathymetric analyses (Kanamatsu et al. 2014), seamount subduction could have affected the study area (Fig. 1; Kimura et al. 2011) and resulted in a change in slope orientation from NESW to NW-SE (the present slope). This seamount subduction might also have been responsible for the occurrence of MTDs between 0.3 and 0.5 Ma. For the youngest MTD phase (MTD 1), which begun with the end of the last glacial, no plausible tectonic activity has yet been described, but we speculate that it may relate to the current phase of recent megasplay fault activity (Moore et al. 2007). Importantly, the reconstructed tectonic uplift phases (before $0.9 \mathrm{Ma}$ and at $\sim 0.5 \mathrm{Ma}$ ) would also have affected the gas hydrate stability zone and may therefore have preconditioned the slopes, making them more prone to submarine landsliding.

\section{Conclusions}

Using a combination of isotope stratigraphy and tephrochronology, we present a 1 Ma record of MTDs in the Nankai Trough, offshore Japan. All of the MTDs occurred within interglacial periods, which might indicate climate is a key preconditioning agent for landslide generation. The occurrence of MTDs also coincides with changes in the tectonic framework, which therefore might also precondition slope failures, but whether an earthquake constitutes the final trigger cannot be resolved from the resolution of the data. Our conclusion is 
that within the investigated $1 \mathrm{Ma}$ period, the relative contributions of tectonic vs. climate preconditioning factors cannot be simply resolved. Therefore, based on our single drill site, our discussion on various forcing mechanisms, including both tectonic and climatic, remains speculative. Further studies are needed to establish longterm, continuous MTD records to better elucidate the preconditioning factors that govern slope failures.

\section{Acknowledgements}

This research used samples provided by the Integrated Ocean Drilling Program (IODP). This work was founded by the Swiss National Science Foundation (number 133481). GP and SV are supported by the Norwegian Research Council through its Centre of Excellence funding scheme (number 223259). KK is currently working at the Swiss Seismological Service, ETH Zurich (Switzerland). We thank Ursula Brupbacher for picking the foraminiferas and the climate geology group of ETH Zurich for measuring the isotope composition. We also thank two anonymous reviewers and the editor, Ken Ikehara, for helpful reviews.

\section{Funding}

Not applicable.

\section{Authors' contributions}

MS proposed the topic. MU and KK carried out the experimental study. KK analyzed the data. YS and YN provided the tephra data. SV and GP helped with the interpretation. KK wrote the manuscript with the contribution of all authors. All authors read and approved the final manuscript.

\section{Competing interests}

The authors declare that they have no competing interests.

\section{Publisher's Note}

Springer Nature remains neutral with regard to jurisdictional claims in published maps and institutional affiliations.

\section{Author details \\ 'Geological Institute, ETH Zurich, Sonneggstrasse 5, 8092 Zürich, Switzerland. ${ }^{2}$ Present address: Swiss Seismological Service, ETH Zurich, Sonneggstrasse 5, 8092 Zurich, Switzerland. ํ.ake Biwa Museum, 1091 Oroshimo, Kusatsu, Shiga 525-0001, Japan. ${ }^{4}$ Faculty of Symbiotic Systems Science, Fukushima University, 1 Kanayagawa, Fukushima 960-1296, Japan. ${ }^{5}$ Centre for Arctic Gas Hydrate, Environment and Climate (CAGE), Department of Geosciences, UiT The Arctic University of Norway, Dramsveien 201, 9037 Tromsø, Norway. ${ }^{6}$ Institute of Geology, University Innsbruck, Innrain 52, 6020 Innsbruck, Austria.}

Received: 11 October 2016 Accepted: 3 July 2017

Published online: 25 July 2017

\section{References}

Ando M (1975) Source mechanisms and tectonic significance of historical earthquakes along the Nankai Trough, Japan. Tectonophysics 27(2):119-140, http://dx.doi.org/10.1016/0040-1951(75)90102-X

Bangs NL, Hornbach MJ, Moore GF, Park J-O (2010) Massive methane release triggered by seafloor erosion offshore southwestern Japan. Geology 38(11): 1019-1022. doi:10.1130/g31491.1

Bassinot FC, Labeyrie L, Vincent E, Quidelleur X, Shackleton NJ, Lancelot Y (1994) The astronomical theory of climate and the age of the Brunhes-Matuyama magnetic reversal. Earth Planet Sci Lett 126(1-3):91-108. doi:10.1016/0012$821 \times(94) 90244-5$

Behrmann J, Völker D, Geersen J, Harders R, Weinrebe W (2014) Size-frequency relationship of submarine landslides at convergent plate margins: implications for hazard and risk assessment. In: Krastel S, Behrmann J-H Völker D et al. (eds) Submarine Mass Movements and Their Consequences, vol 37. Advances in Natural and Technological Hazards Research. Springer International Publishing, pp 165-175. doi:10.1007/978-3-319-00972-8_15
Blaauw M (2010) Methods and code for 'classical' age-modelling of radiocarbon sequences. Quaternary Geochronology 5(5):512-518. doi:10.1016/..quageo. 2010.01.002

Breitenbach SFM, Bernasconi SM (2011) Carbon and oxygen isotope analysis of small carbonate samples (20 to $100 \mu \mathrm{g}$ ) with a GasBench II preparation device. Rapid Commun Mass Spectrom 25(13):1910-1914. doi:10.1002/rcm.5052

Brothers DS, Luttrell KM, Chaytor JD (2013) Sea-level-induced seismicity and submarine landslide occurrence. Geology 41:979-998

Buchs DM, Cukur D, Masago H, Garbe-Schönberg D (2015) Sediment flow routing during formation of forearc basins: constraints from integrated analysis of detrital pyroxenes and stratigraphy in the Kumano Basin, Japan. Earth Planet Sci Lett 414:164-175, http://dx.doi.org/10.1016/j.epsl.2014.12.046

Gulick SPS, Bangs NLB, Moore GF, Ashi J, Martin KM, Sawyer DS, Tobin HJ, Kuramoto S, Taira A (2010) Rapid forearc basin uplift and megasplay fault development from 3D seismic images of Nankai Margin off Kii Peninsula, Japan. Earth Planet Sci Lett 300(1-2):55-62, http://dx.doi.org/10.1016/j.epsl. 2010.09.034

Hayashida A, Kamata H, Danhara T (1996) Correlation of widespread tephra deposits based on paleomagnetic directions: link between a volcanic field and sedimentary sequences in Japan. Quat Int 34-36(0):89-98, http://dx.doi. org/10.1016/1040-6182(95)00072-0

Henry P, Kanamatsu T, Moe KT, Strasser M, Party tIES (2012) IODP expedition 333: return to Nankai Trough subduction inputs sites and coring of mass transport deposits. Scientific Drilling 14:4-17

Henstock TJ, McNeill LC, Tappin DR (2006) Seafloor morphology of the Sumatran subduction zone: surface rupture during megathrust earthquakes? Geology 34(6):485-488. doi:10.1130/22426.1

Ikari MJ, Strasser M, Saffer DM, Kopf AJ (2011) Submarine landslide potential near the megasplay fault at the Nankai subduction zone. Earth Planet Sci Lett 312(3-4):453-462, http://dx.doi.org/10.1016/j.epsl.2011.10.024

Ikehara K, Danhara T, Yamashita T, Tanahashi M, Morita S, Ohkushi K (2011) Paleoceanographic control on a large marine reservoir effect offshore of Tokai, south of Japan, NW Pacific, during the last glacial maximumdeglaciation. Quat Int 246:213-221

Iwatani H, Kondo Y, Irizuki T, Iwai M, Ikehara M (2016) Orbital obliquity cycles recorded in Kuroshio Current region, eastern Asia, around Plio-Pleistocene boundary. Quaternary Science Reviews 140:67-74, http://dx.doi.org/10.1016/j. quascirev.2016.03.025

Kanamatsu T, Kawamura K, Strasser M, Novak B, Kitamura Y (2014) Flow dynamics of Nankai Trough submarine landslide inferred from internal deformation using magnetic fabric. Geochem Geophys Geosyst 15(10):4079-4092. doi:10. 1002/2014GC005409

Kawamura K, Sasaki T, Kanamatsu T, Sakaguchi A, Ogawa Y (2012) Large submarine landslides in the Japan Trench: a new scenario for additional tsunami generation. Geophys Res Lett 39(5):n/a-n/a. doi:10.1029/ 2011GL050661

Kimura G, Moore GF, Strasser M, Screaton E, Curewitz D, Streiff C, Tobin H (2011) Spatial and temporal evolution of the megasplay fault in the Nankai Trough. Geochem Geophys Geosyst 12(3):Q0A008. doi:10.1029/2010GC003335

Kimura J-I, Nagahashi Y, Satoguchi Y, Chang Q (2015) Origins of felsic magmas in Japanese subduction zone: geochemical characterizations of tephra from caldera-forming eruptions <5 Ma. Geochem Geophys Geosyst 16(7):21472174. doi:10.1002/2015GC005854

Kinoshita M, Moore GF, Kido YN (2011) Heat flow estimated from BSR and IODP borehole data: implication of recent uplift and erosion of the imbricate thrust zone in the Nankai Trough off Kumano. Geochem Geophys Geosyst 12(9):QOAD18. doi:10.1029/2011GC003609

Kuwae M, Yoshikawa S, Inouchi Y (2002) A diatom record for the past 400 ka from Lake Biwa in Japan correlates with global paleoclimatic trends. Palaeogeography, Palaeoclimatology, Palaeoecology 183(3-4):261-274, http://dx.doi.org/10.1016/50031-0182(01)00490-4

Lisiecki LE, Raymo ME (2005) A Pliocene-Pleistocene stack of 57 globally distributed benthic $\delta 180$ records. Paleoceanography 20(1):PA1003. doi:10. 1029/2004PA001071

Maslin M, Owen M, Betts R, Day S, Dunkley Jones T, Ridgwell A (2010) Gas hydrates: past and future geohazard? Philosophical Transactions of the Royal Society A: Mathematical, Physical and Engineering Sciences 368:2369-2393. doi:10.1098/rsta.2010.0065

Masson DG, Harbitz CB, Wynn RB, Pedersen G, Løvholt F (2006) Submarine landslides: processes, triggers and hazard prediction. Philos Trans R Soc 364: 1845. doi:10.1098/rsta.2006.1810 
Moore GF, Bangs NL, Taira A, Kuramoto S, Pangborn E, Tobin HJ (2007) Threedimensional splay fault geometry and implications for tsunami generation. Science 318(5853):1128-1131. doi:10.1126/science.1147195

Moore GF, Park J-O, Bangs NLB, Gulick SPS, Tobin HJ, Nakamura Y, Sato S, Tusji T, Yoro T, Tanaka H, Uraki S, Kido Y, Sanada Y, Kuramoto S, Taira A (2009) Structural and seismic stratigraphic framework of the NanTroSEIZE Stage 1 transect, Proceedings of the Integrated Ocean Drilling Program 314/315/316

Nagahashi Y, Yoshida T, Nakai S, Okudaira T (2003) Evaluation and correction of EDS results of the glass shards from some representative tephra by comparison with XRF analysis. The Quaternary Research (Daiyonki-Kenkyu) 42(4):265-277. doi:10.4116/jaqua.42.265

Nagahashi Y, Yoshikawa S, Miyakawa C, Uchiyama T, Inouchi Y (2004) Stratigraphy and chronology of widespread tephra layers during the past 430ky in the Kinki District and the Yatsugatake Mountains--major element composition of the glass shards using EDS analysis. The Quaternary Research (DaiyonkiKenkyu) 43(1):15-35. doi:10.4116/jaqua.43.15

Nagahashi Y, Nakai S, Kikkawa K, Okudaira T, Yoshikawa S, Yoshida T (2015) Petrological properties of tephra beds based on the major and trace element composition of volcanic glass shards : a case study of the Osaka Group and the Takashima-oki drilling core sediments in Lake Biwa, Kinki district, Japan. Earth Science (Chikyu-kagaku) 69(4):205-222

Owen M, Day S, Maslin M (2007) Late Pleistocene submarine mass movements: occurrence and causes. Quaternary Science Reviews 26:958-978, http://dx. doi.org/10.1016/j.quascirev.2006.12.011

Pickering KT, Souter C, Oba T, Taira A, Schaaf M, Platzman E (1999) Glacio-eustatic control on deep-marine clastic forearc sedimentation, Pliocene-midPleistocene (c. 1180-600 ka) Kazusa Group, SE Japan. J Geol Soc London 156: 125-136. doi:10.1144/gsjgs.156.1.0125

Reimer PJ, Bard E, Bayliss A, Beck JW, Blackwell PG, Ramsey CB, Buck CE, Cheng $H_{\text {, }}$ Edwards RL, Friedrich M, Grootes PM, Guilderson TP, Haflidason H, Hajdas I, Hatte C, Heaton TJ, Hoffmann DL, Hogg AG, Hughen KA, Kaiser KF, Kromer B, Manning SW, Niu M, Reimer RW, Richards DA, Scott EM, Southon JR, Staff RA, Turney CSM, van der Plicht J (2013) Intcal13 and Marine13 radiocarbon age calibration curves, 0-50,000 years cal BP. Radiocarbon 55(4):1869-1887

Sawada K, Handa N (1998) Variability of the path of the Kuroshio ocean current over the past 25,000 years. Nature 392:592-595

Seno T, Stein S, Gripp AE (1993) A model for the motion of the Philippine Sea Plate consistent with NUVEL-1 and geological data. J Geophys Res Solid Earth 98(B10):17941-17948. doi:10.1029/93JB00782

Shishikura M, Echigo T, Kaneda H (2007) Marine reservoir correction for the Pacific coast of central Japan using 14C ages of marine mollusks uplifted during historical earthquakes. Quatern Res 67:286-291

Siddall M, Hönisch B, Waelbroeck C, Huybers P (2010) Changes in deep Pacific temperature during the mid-Pleistocene transition and Quaternary. Quaternary Science Reviews 29(1-2):170-181, http://dx.doi.org/10.1016/j.quascirev.2009.05.011

Sloan ED, Koh CA (2008) Clathrate hydrates of natural gases, 3rd edn. CRC Press, Boca Ration

Smith DE, Harrison S, Jordan JT (2013) Sea level rise and submarine mass failures on open continental margins. Quaternary Science Reviews 82:93-103, http:// dx.doi.org/10.1016/j.quascirev.2013.10.012

Stern JV, Lisiecki LE (2014) Termination 1 timing in radiocarbon-dated regional benthic $\delta 180$ stacks. Paleoceanography 29(12):2014PA002700. doi:10.1002/ 2014PA002700

Strasser M, Moore GF, Kimura G, Kitamura Y, Kopf AJ, Lallemant S, Park J-O, Screaton EJ, Su X, Underwood MB, Zhao X (2009) Origin and evolution of a splay fault in the Nankai accretionary wedge. Nat Geosci 2(9):648-652, http:// www.nature.com/ngeo/journal/v2/n9/suppinfo/ngeo609_S1.html

Strasser M, Moore GF, Kimura G, Kopf AJ, Underwood MB, Guo J, Screaton EJ (2011) Slumping and mass transport deposition in the Nankai fore arc: evidence from IODP drilling and 3-D reflection seismic data. Geochem Geophys Geosyst 12(5):Q0AD13. doi:10.1029/2010GC003431

Strasser M, Henry P, Kanamatsu T, Thu M, Moore G (2012) Scientific Drilling of mass-transport deposits in the Nankai accretionary wedge: first results from IODP expedition 333. In: Yamada Y, Kawamura K, Ikehara K et al. (eds) Submarine Mass Movements and Their Consequences, vol 31. Advances in Natural and Technological Hazards Research. Springer Netherlands, pp 671681. doi:10.1007/978-94-007-2162-3_60

Strasser M, Kölling M, Ferreira CS, Fink HG, Fujiwara T, Henkel S, Ikehara K, Kanamatsu T, Kawamura K, Kodaira S, Römer M, Wefer G, SO219A RVSC, scientists JCM-E (2013) A slump in the trench: tracking the impact of the 2011 Tohoku-Oki earthquake. Geology 41(8):935-938. doi:10.1130/g34477.1
Sultan N, Cochonat P, Foucher JP, Mienert J (2004) Effect of gas hydrates melting on seafloor slope instability. Mar Geol 213(1-4):379-401, http://dx.doi.org/10. 1016/j.margeo.2004.10.015

Suzuki T, Eden D, Danhara T, Fujiwara O (2005) Correlation of the HakkodaKokumoto Tephra, a widespread Middle Pleistocene tephra erupted from the Hakkoda Caldera, northeast Japan. Island Arc 14(4):666-678. doi:10.1111/j. 1440-1738.2005.00475.x

Tappin DR, Grilli ST, Harris JC, Geller RJ, Masterlark T, Kirby JT, Shi FY, Ma GF, Thingbaijam KKS, Mai PM (2014) Did a submarine landslide contribute to the 2011 Tohoku tsunami? Mar Geol 357:344-361. doi:10.1016/j.margeo.2014.09.043

Urlaub M, Talling PJ, Masson DG (2013) Timing and frequency of large submarine landslides: implications for understanding triggers and future geohazard. Quaternary Science Reviews 72(0):63-82, http://dx.doi.org/10.1016/j.quascirev. 2013.04.020

Usman M, Masago H, Winkler W, Strasser M (2014) Mid-Quaternary decoupling of sediment routing in the Nankai Forearc revealed by provenance analysis of turbiditic sands. Int J Earth Sci (Geol Rundsch) 103(4):1141-1161. doi:10.1007/s00531-014-1011-z

Völker D, Scholz F, Geersen J (2011) Analysis of submarine landsliding in the rupture area of the 27 February 2010 Maule earthquake, Central Chile. Mar Geol 288(1-4):79-89, http://dx.doi.org/10.1016/j.margeo.2011.08.003

Yamada Y, Yamashita Y, Yamamoto Y (2010) Submarine landslides at subduction margins: insights from physical models. Tectonophysics 484:156-157

Yamano M, Kawada Y, Hamamoto $\mathrm{H}$ (2014) Heat flow survey in the vicinity of the branches of the megasplay fault in the Nankai accretionary prism. Earth Planet Sp 66(1):126

Yoneda M, Uno H, Shibata Y, Suzuki R, Kumamoto Y, Yoshida K, Sasaki T, Suzuki A, Kawahata H (2007) Radiocarbon marine reservoir ages in the western Pacific estimated by pre-bomb molluscan shells. Nuclear Instruments and Methods in Physics Research Section B: Beam Interactions with Materials and Atoms 259:432-437

Yoshikawa S, Mitamura M (1999) Quaternary stratigraphy of the Osaka Plain, central Japan and its correlation with oxygen isotope record from deep sea cores. The Journal of the Geological Society of Japan 105(5):332-340. doi:10.5575/geosoc.105.332

\section{Submit your manuscript to a SpringerOpen ${ }^{\mathcal{O}}$ journal and benefit from:}

- Convenient online submission

- Rigorous peer review

- Open access: articles freely available online

- High visibility within the field

- Retaining the copyright to your article

Submit your next manuscript at $>$ springeropen.com 